\title{
PENERAPAN SISTEM INFORMASI LAYANAN PRINT ONLINE
}

\author{
Jihan Fadhilah $^{1}$, Rahmat Hidayat ${ }^{2}$, Yulindon ${ }^{3}$ \\ Teknologi Rekayasa Perangkat Lunak/Teknologi Informasi, Politeknik Negeri Padang ${ }^{1}$ \\ Email : jihannfadhilahh13@gmail.com¹, rahmat@pnp.ac.id ${ }^{2}$, yulindon@pnp.ac.id ${ }^{3}$
}

\begin{abstract}
ABSTRAK
Mahasiswa seringkali mendapatkan tugas-tugas yang harus dicetak seperti makalah, laporan, skripsi, dan sebagainya sehingga kegiatan cetak dokumen menjadi sangat sering dilakukan. Kegiatan cetak dokumen di luar terasa sangat mengganggu produktivitas para mahasiswa karena dengan begitu mereka harus berjalan menuju tempat print, mengantre, dan sibuk mencari tempat print yang buka. Cuaca yang sering tidak mendukung serta harga cetak yang tidak sesuai juga menjadi salah satu faktor kurangnya kepuasan pelanggan atas solusi mencetak di luar. Dalam penelitian ini penulis mencoba untuk menyelesaikan persoalan di atas dengan membuat sebuah sistem e-business web-to-print dimana pelanggan hanya tinggal upload lalu pilih lokasi dimana ia akan mengambil hasil cetak dokumennya dan jika dokumen selesai pelanggan akan mendapatkan pemberitahuan dan ia dapat mengambil dokumennya. Penelitian dilakukan dari tahapan analisis kebutuhan, perancangan, implementasi, sampai pengujian.
\end{abstract}

\section{Kata Kunci: Informasi, Layanan, Online, Print, Sistem}

\begin{abstract}
The university student often receive assignments that need to be printed such as essay, reports, thesis, etc so that the document printing activity is neccessary for them. Outside printing activity feels very disturbing students' productivity because with that they must to walk to printing services, queue and be busy to find open printing services. In this research writer tries to solve the above issues with making a web-to-print e-business system. In this system customers just need to upload and choose the store where they want to take the document and after the document done he will receive notification and can take his document. The research done from requirement analysis stage, designing, implementation until testing stage.
\end{abstract}

\section{Keywords: Information, Services, Online, Print, System}

\section{PENDAHULUAN}

Percetakan adalah sebuah proses industri untuk memproduksi secara massal tulisan dan gambar. Jasa cetak saat ini semakin banyak dibutuhkan masyarakat karena dapat mempermudah dalam penyampaian suatu informasi. Dalam satu hari sebuah percetakan dapat memproduksi sampai dengan ribuan bahan atau produk percetakan yang dihasilkan. Percetakan menjadi salah satu penemuan yang penting dan cukup berpengaruh dalam sejarah kehidupan manusia. Percetakan merupakan sebuah komunikasi massa yang dapat digunakan sejak pertengahan tahun 1400-an hingga awal 1900-an. Percetakan 
dalam masa sekarang ini dapat dikategorikan sebagai industri penting di berbagai negara, khususnya negara maju di dunia. Sistem percetakan pada saat ini masih menggunakan sistem konvensional dalam transaksinya sehingga masih sering terjadi kesalahan dalam pembuatan laporan. Maka sistem ini akan mempermudah proses pemesanan, transaksi pemesanan dan pembayaran pada percetakan.

Pada zaman sekarang, perkembangan teknologi khususnya teknologi informasi sangat cepat dan mulai merata di seluruh aspek kehidupan. Jadi, pada saat ini kebutuhan pelanggan akan produk percetakan seperti mencetak dokumen semakin meningkat. Akan tetapi seringkali kesibukan yang padat atau jarak yang jauh ataupun halangan lainnya membuat mereka menjadi malas atau bahkan enggan untuk mencetak dipercetakan tersebut tidak hanya itu saja, informasi mengenai produk dan jasa yang disediakan oleh sebuah mitra percetakan serta harga yang ditawarkannya juga minim sekali sehingga menyebabkan pelanggan menjadi kesulitan dalam menyesuaikan dengan selera dan anggaran yang dimilikinya. Selama ini system yang di buat hanya dalam bentuk WEB dengan cara memesan dokumen yang akan di cetak (Arief, Brata, \& Dewi, 2018) (Mujtaba Habibi dan Sudirman, 2013) (Fauzi, Wibowo, \& Putri, 2018). Tetapi, belum menyediakan sistem pesan antar. Jadi pada paper akan mengkaji tentang cara sistem pesan antar untuk mempermudah pelanggan.

Paper ini akan mengkaji lebih jauh mengenai sistem informasi percetakan yang telah diterapkan pada berbagai institusi. Kajian akan dikembangkan dalam berbagai aspek seperti metoda, perkembangan, khalayak sasaran, wilayah, dsb. Pada bagian akhir akan disampaikan prospek atau kemungkinan pengembangan sistem ini beserta tantangan yang dihadapi. Paper ini nantinya akan bermanfaat sebagai referensi untuk mengkaji sebuah system informasi print online yang ingin di bahas.

\section{LANDASAN TEORI}

2.1. Definisi Sistem Informasi

Sistem informasi merupakan sistem yang berisi jaringan SPD (Sistem Pengolahan data), yang dilengkapi dengan kanal-kanal komunikasi yang digunakan dalam sistem organisasi data. Elemen proses dari sistem informasi antara lain mengumpulkan data (data gathering), mengolah data yang tersimpan,menyebarkan informasi (Kotler, 1998)

\subsection{Definisi pemesanan}

Dalam bukunya Kotler mengatakan pemesanan barang dan jasa adalah suatu kegiatan transaksi yang menyatakan keinginan atau rencana untuk memiliki atau membeli barang dan jasa tersebut sebelum melakukan transaksi finasial yakni berupa pembayaran finasial terhadap produk atau jasa yang diinginkan. (Kotler, 1998)

\section{METODE PENELITIAN}

Pada jurnal yang sudah dikumpulkan sebagian besar pengumpulan data menggunakan metode kepustakaan, survei, dan eksperinmental. Ada juga yang menggunakan metode pengumpulan data dengan mengelompokkan menjadi data primer dan data sekunder, dan juga masih banyak metode yang digunakan dalam sistem informasi pelayanan digital printing. 
Tabel 1. Metode Penelitian

\begin{tabular}{|l|l|}
\hline No & Metode \\
\hline 1 & RUP \\
\hline 2 & SDLC \\
\hline 3 & Agile Development Scrum \\
\hline 4 & Waterfall \\
5 & SWOT \\
\hline
\end{tabular}

Berdasarkan hasil review terhadap penelitian terkait pelayanan digital printing, terdapat berbagai metode yang digunakan dalam sebuah layanan berbasis web seperti terlihat pada Tabel 1 . Metode ini juga didapat dari review terkait artikel print online yang memiliki sistem hampir mirip dengan sistem informasi pelayanan digital printing ini.

\subsection{RUP}

RUP dilakukan secara iteratif (berulang) dan incremental (bertahap dengan progress menaik). (WP, Junainti, \& Sudrajat, 2011)

\subsection{SDLC}

Dalam perancangan menggunakan metode SDLC, metode ini dilaksanakan dengan cara perencanaan, analisis, perancangan, implementasi. (Fergiawan Listianto, Fauzi, Rita Irviani, 2017) (Fauzi et al., 2018)(Fauzi et al., 2018) (Mujtaba Habibi dan Sudirman, 2013)

\subsection{Agile Development Scrum}

Agile Development Scrum akan berfokus dalam pengembangan aplikasi menggunakan acuan pengembangan yang terdapat dalam scrum. (Informatika et al., n.d.)

\subsection{Waterfall}

Waterfall adalah tahapan analisa kebutuhan, tahapan desain sistem, tahapan penulisan kode, tahapan pengujian program, dan terakhir adalah tahapan operasi dan perawatan program. (Fauzi et al., 2018)

\subsection{SWOT}

Metode perencanaan strategis yang digunakan untuk mengevaluasi kekuatan (strengths), kelemahan (weaknesses), peluang (opportunities), dan ancaman (threats) dalam suatu proyek atau suatu spekulasi bisnis. (Juanita, 2017)

\section{HASIL DAN PEMBAHASAN}

Penggunaan sistem pelayanan pemesanan online pada digital printing ini tidak hanya dapat diterapkan untuk orang yang memiliki tempat fotocopy atau orang yang sudah punya tempat printer saja. Tetapi ini juga berlaku untuk mitra yang memiliki mesin printing. Aplikasi pelayanan Digital Printing ini dapat menjadi alternatif transaksi pemesanan dan pembayaran pada percetakan. Hal ini dapat menghemat waktu dan materi.(Kotler, 1998) (WP et al., 2011) (Mujtaba Habibi dan Sudirman, 2013)(Juanita, 2017)(Informatika et al., n.d.)

Berikut hasil dari survei terkait fenomena tersebut ke 56 responden mahasiswa:

1) Lebih dari $50 \%$ responden sering mengalami situasi dimana mereka sedang ada deadline tugas namun harus antre saat mancetak.

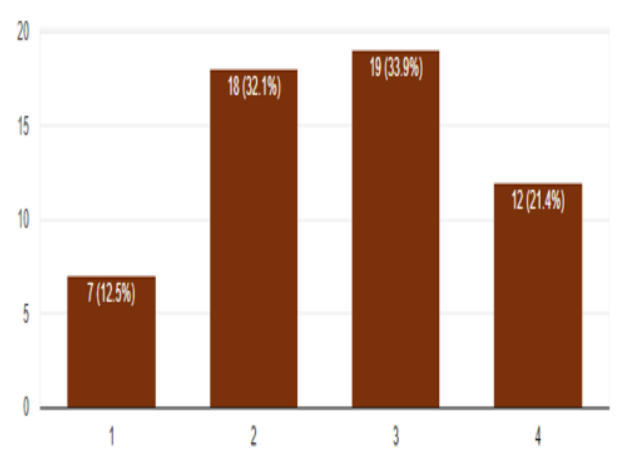

Gambar 1. Tingkat Antri Saat Mencetak 
2) Sebanyak $55.4 \%$ dari 56 responden sangat sering mencetak dan mengumpulkan tugas kuliah dalam bentuk hardcopy

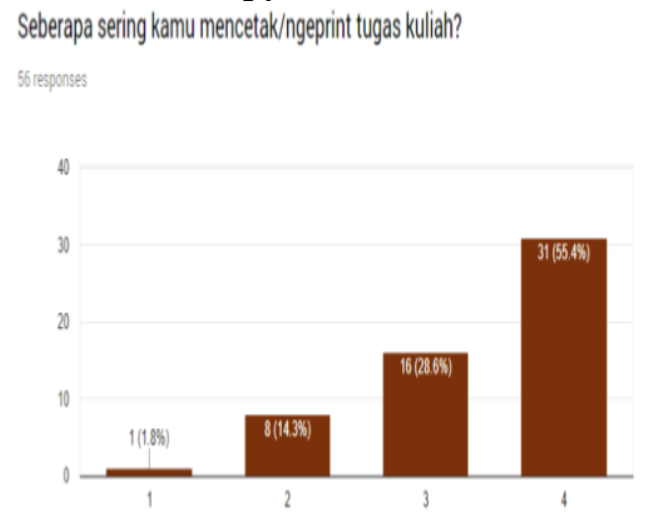

Gambar 2. Intensitas Responden Untuk Mencetak Tugas

Dengan menggunakan sebuah aplikasi berbasis mobile yang dapat dioperasikan pada smartphone berbasis web, memberikan kemudahan bagi pelanggan yang memiliki kesibukan yang padat atau berdomisili jauh dari percetakan digital printing ini. (Irmawati, 2011) (Fauzi et al., 2018) (Situmeang, Ekonomi, Prima, \& Medan, 2018)

\section{SIMPULAN DAN SARAN}

Sistem yang diusulkan untuk melakukan pencetakan dokumen secara online dengan aplikasi piranti bergerak yang dibangun pada penelitian ini terdiri dari tiga aplikasi untuk tiga user yang berbeda yaitu aplikasi mobile untuk customer, aplikasi web untuk mitra outlet, dan aplikasi web untuk admin.

Rancangan sistem ini untuk cetak dokumen secara online dengan aplikasi piranti bergerak dilakukan dengan menggunakan sequence diagram, class diagram, dan entity relationship diagram dimana rancangan tersebut dapat dimanfaatkan untuk implementasi sistem e-business untuk cetak dokumen secara online dengan aplikasi piranti bergerak.

Implementasi sistem ini untuk cetak dokumen secara online bergerak dilakukan dengan melakukan implementasi basis data dengan physical data model, implementasi class, implementasi kode program dengan menggunakan framework.

\section{DAFTAR PUSTAKA}

Arief, Z. El, Brata, A. H., \& Dewi, R. K. (2018). Pengembangan Sistem EBusiness untuk Cetak Dokumen Kapan Saja dan Dimana Saja Secara Online dengan Aplikasi Piranti Bergerak. Jurnal Pengembangan Teknologi Informasi Dan Ilmu Komputer (J-PTIIK) Universitas Brawijaya, 2(5), 2043-2049.

Fauzi, R., Wibowo, S., \& Putri, D. Y. (2018). Perancangan Aplikasi Marketplace Jasa Percetakan Berbasis Website. Fountain of Informatics Journal, $3(1), \quad 5$. https://doi.org/10.21111/fij.v3i1.1824 Fergiawan Listianto, Fauzi, Rita Irviani, K. (2017). Aplikasi E-Commerce Berbasis Web Mobile Pada Industri Konveksi Seragam Drumband Di Pekon Klaten Gadingrejo Kabupaten Pringsewu. Jurnal TAM ( Technology Acceptance Model ), 8(2), 146-152.

Informatika, T., Komputer, I., Tinggi, S., Terpadu, T., Fikri, N., \& Kom, M. (n.d.). Irfan Asidiq.

Irmawati, D. (2011). Pemanfaatan ECommerce Dalam Dunia Bisnis. Orasi Bisnis, VI(November), 95-112.

Juanita, S. (2017). Analisa Strategi Bisnis Penjualan Online. Konferensi Nasional ICT-M Politeknik Telkom, 254-260. Retrieved from http://journals.telkomuniversity.ac.id/ knip/article/view/557 
Kotler. (1998). Sistem Informasi Pemesanan Dan Pembayaran Pada Percetakan Mahardika. On Computer Science - Speed - FTI UNSA.

Mujtaba Habibi dan Sudirman, M. (2013). Ilyas, Sistem Informasi Pencetakan Berbasis Web Pada Percetakan Ade Printing Tembilahan 1. Jurnal Sistemasi, 2, 1-14.

Situmeang, R. R., Ekonomi, F., Prima, U., \& Medan, I. (2018). Dampak Bisnis
Online Dan Lapangan Pekerjaan Terhadap Peningkatan Pendapatan Masyarakat (Studi Kasus Jasa Bisnis Online Transportasi Grab Di Kota Medan). 03(September), 319-335.

WP, L., Junainti, F., \& Sudrajat, W. A. (2011). Aplikasi Pelayanan Pemesanan Online Pada Digital Printing Ecoprint Palembang. Stmik Gi Mdp. 